\title{
PANDANGAN KIYAI TENTANG PENINGKATAN MUTU KAJIAN KITAB KUNING DI PESANTREN
}

\author{
Nunu Ahmad An-Nahidl \\ Peneliti Puslitbang Pendidikan Agama dan Keagamaan | Balitbang dan Diklat Kemenag RI \\ Jl. MH Thamrin No. 06 Jakarta Pusat | Email: Intersym2013@gmail.com
}

\begin{abstract}
Survey of opinion of kiyai on the improvement of quality of study of Kitab Kuning in Pesantren was done in 2014 aimed at finding data and information on expectation of kiyais on aspects of input, process and output of study of kitab kuning in pesantrens. Data was obtained from 22 provinces with 711 kiyais as the samples with systematical random technique. The survey showed that most kiyais give high responses on the indikators used to measure variables of input, process and output. It means that the survey is a factual testimony that most kiyais have positive opinion on the improvement of quality of study of Kitab Kuning in Pesantren
\end{abstract}

Keywords: kitab kuning, quality, pesantren

\begin{abstract}
Abstrak
Survai Pandangan Kiyai tentang Peningkatan Mutu Kajian Kitab Kuning di Pesantren dilakukan tahun 2014, dengan tujuan menggali data dan informasi tentang harapan kiyai terhadap aspek-aspek input, proses dan output kajian kitab kuning di pesantren. Pengumpulan data dilakukan di 22 propinsi dengan jumlah sampel sebanyak 711 kiyai yang dipilih dengan teknik acak sistematis. Hasil survai menyimpulkan bahwa rata-rata kiyai memberikan respon tinggi terhadap indikator yang digunakan untuk mengukur variabel input, proses dan output. Artinya, temuan survai ini menjadi testimoni faktual bahwa rata-rata kiyai memiliki pandangan positif terhadap peningkatan mutu kajian kitab kuning di pesantren.
\end{abstract}

Kata kunci: kitab kuning, mutu, pesantren

\section{PENDAHULUAN}

Pesantren adalah lembaga pendidikan pencetak dan pengkaderan ulama. Sebagian besar ulama di tanah air dilahirkan oleh pendidikan pesantren dan sejenisnya. Maka tugas utama pesantren sebagai lembaga pendidikan reproduksi ulama hendaknya tetap dipertahankan keberlangsungannya. Tegasnya, pesantren yang berkembang saat ini menjadi sangat penting untuk terus didorong agar tetap mampu melahirkan ulama-ulama mutafaqqih fid-din.

Mengkader seorang calon ulama jelas tidak mudah dan sederhana, terutama di tengah dunia pendidikan saat ini yang jauh semakin kompetitif. Sementara, jumlah lembaga pendidikan pesantren yang tetap mempertahankan fungsi dan peran tafaqquh fid-din dengan konsentrasi kepada kajian kitab kuning tinggal sedikit, dan masing-masing memiliki kurikulum dan standar kelulusan yang beragam. ${ }^{1}$

Saat ini pendidikan umum formal seperti madrasah dan sekolah didirikan di lingkungan

1 Lihat: Badan Litbang dan Diklat. 2011. Survei Pengajaran Kitab Kuning di Pondok Pesantren. Jakarta: Puslitbang Pendidikan Agama dan Keagamaan, h. 130133. 
pesantren untuk menarik minat orang tua 'menitipkan' anaknya di pesantren, dan sebagai jawaban atas kebutuhan santri terhadap legalitas tanda kelulusan pendidikan formal. Namun pendirian pendidikan umum formal itu tidak diikuti upaya peningkatan mutu kajian kitab kuningnya, bahkan cenderung mengabaikannya. Akhirnya, kajian kitab kuning di pesantren hanya berfungsi takmili atas pendidikan umum formalnya. Santri sendiri lebih banyak menghabiskan waktu pembelajarannya di sekolah atau madrasah, dan pesantren lebih sebagai boarding belaka. ${ }^{2}$

Hasil survai Puslitbang Pendidikan Agama dan Keagamaan tahun 2011, menyimpulkan bahwa; 1) terdapat varian kitab kuning yang dikaji di pesantren pada setiap bidang keilmuan dilihat dari jenisnya, waktu pembelajarannya, dan pilihan atas kitab yang dikaji; dan 2) waktu pembelajaran kitab kuning dan jumlahnya pada setiap bidang keilmuan tergolong rendah atau menurun. Survai ini merekomendasikan kepada Kementerian Agama untuk menyusun pedoman pengajaran kitab kuning di pesantren. ${ }^{3}$

Pertemuan para ulama pengasuh pesantren di Surabaya tahun 2013 tentang "Penguatan Tradisi Keilmuan di Pondok Pesantren," yang digagas Puslitbang Pendidikan Agama dan Keagamaan telah menghasilkan sejumlah kesimpulan penting. Antara lain, para ulama mendorong pendidikan pesantren untuk tetap dapat mengadaptasi perkembangan kehidupan dan kebutuhan masyarakat, namun dengan tetap mengemban misi tafaqquh fiddin demi melahirkan ulama yang mumpuni. Para ulama juga meminta kepada Kementerian Agama untuk memfasilitasi penyusunan kuri-

${ }^{2}$ Berdasarkan observasi langsung peneliti, pola ini misalnya ditemukan pada sebuah pondok pesantren yang justeru cukup populer di daerah priangan Jawa Barat.

${ }^{3}$ Badan Litbang dan Diklat. 2011. Survei Pengajaran Kitab Kuning di Pondok Pesantren. Jakarta: Puslitbang Pendidikan Agama dan Keagamaan, h. 130-133. kulum tafaqquh fid-din yang terstandar bagi pesantren. ${ }^{4}$

Berpijak kepada hasil penelitian dan pertemuan ulama tadi, maka tampak jelas bahwa kurikulum tafaqquh fid-din yang terstandar dibutuhkan. Manfaatnya antara lain untuk: 1) mendorong seluruh pesantren di tanah air agar tetap memiliki semangat dan potensi yang sama dalam melahirkan calon ulama; 2) memastikan setiap santri di pesantren memperoleh pembelajaran kitab kuning pada setiap bidang keilmuan sesuai dengan jenjang pendidikannya masingmasing; 3) menjadi acuan bersama bagi setiap pesantren dalam melakukan upaya penguatan kajian kitab kuning.

Masalah dalam penelitian ini adalah bagaimana pandangan kiai terhadap peningkatan mutu kajian kitab kuning di pesantren pada tiga aspek, yaitu aspek input, proses dan output. Penelitian ini menjadi penting untuk mempersiapkan sejumlah instrumen pendidikan yang dibutuhkan dalam perencanaan, pelaksanaan dan evaluasi pendidikan pesantren ke depan, khususnya kajian kitab kuning di pesantren.

Hasil penelitian ini diharapkan menjadi masukan strategis bagi Kementerian Agama dalam merumuskan kebijakan Pemerintah tentang peningkatan mutu pendidikan pesantren, khususnya pada aspek kajian kitab kuningnya yang menjadi unsur utama pembelajaran di pesantren.

\section{Kerangka Teori}

\section{Pondok Pesantren dan Pengembangan Pendidikan}

Pesantren memiliki parameter yang terukur ketika dihadapkan kepada pilihan pengembangan pendidikan ke depan. Kaidah

${ }^{4}$ Badan Litbang dan Diklat. 2013. Laporan Halaqah Ulama tentang "Penguatan Tradisi Keilmuan di Pondok Pesantren. Jakarta: Puslitbang Pendidikan Agama dan Keagamaan, h. 99-101. 
"al-muhafazhat ala al-qadim ash-shalih wa alakhdzu bi al-jadid al-ashlah," dapat dimaknai sebagai upaya pesantren mengawal keberlangsungan dengan cara memacu inovasi dan kreativitas. Al-jadid al-ashlah itu tidak berarti lebih baik dari yang lama, namun lebih tepatnya, ia merelevansi kebutuhan saat ini, dimana kehidupan manusia terus berubah mengikuti perkembangan kemajuan jaman. Namun demikian, tantangan modernitas dengan sistem pendidikan yang ditawarkannya, ternyata tidak mudah diterima begitu saja.

Paling tidak terdapat tiga (3) varian respon pesantren atas tawaran pengembangan pendidikan. Pertama, menerima bahkan beralih dengan mengembangkan sistem pendidikan umum, yaitu sekolah dan madrasah. Pada model ini, dominasi penguatan pendidikan umum justeru merubah fungsi pesantren menjadi lebih semacam asrama (boarding). Santri mengaji telah berubah menjadi siswa belajar sepanjang hari di sekolah atau madrasah. Sekalipun masih ada pengajian kitab kuning, maka jumlah jam belajar dan pilihan standar kitabnya terhitung dalam kategori rendah. Tetapi lembaga pendidikan ini masih menyebut dirinya pondok pesantren. ${ }^{5}$

Kedua, menolak pengembangan dan bertahan dengan pola lama yang telah berjalan. Pada model ini, pesantren tetap mempertahankan tradisi pengembangan intelektual pada sistem pendidikannya dengan berbasis kitab kuning. Santri pemula biasanya dianjurkan untuk mempelajari sejumlah kitabkitab dasar dengan model sorogan dengan penekanan kepada muhafadzah (hapalan). Sementara untuk kitab-kitab menengah dan atas, dipelajari oleh santri dengan model bandongan.

Ketiga, mengambiljalantengah.Padamodel ini, pesantren melakukan pengembangan sistem pendidikan dengan menyelenggarakan pendidikan umum, namun dengan tetap

${ }^{5}$ Nunu Ahmad An-Nahidl, dkk (Editor). 2010. Otoritas Pesantren dan Perubahan Sosial. Jakarta: Puslitbang Pendidikan Agama dan Keagamaan, h. 147-149. mempertahankan kajian kitab kuningnya, dan diposisikan sebagai pendidikan takhassus, dimana santrinya tidak lagi mengikuti jenis pendidikan lain (sekolah atau madrasah). Pada pendidikan takhassus, pembelajaran kitab kuning menggunakan sistem klasikal dimana pilihan atas kitab yang dipelajari, standarnya disesuaikan dengan jenjang yang ada, mulai Ula, Wustha, Ulya dan Ma'had Ali. Pada model ketiga ini, sudah mulai dikembangkan metode musyawarah atau mudzakarah kitab, tidak lagi sorogan dan bandongan. Di beberapa pesantren yang tidak mengembangkan pendidikan takhassus, kajian kitab kuning 'dititipkan' pada pendidikan madrasah, baik sebagai mata pelajaran kurikuler maupun menjadi bagian dari kegiatan ekstra kurikuler. ${ }^{6}$

Ketiga model tersebut merupakan varian sikap yang diekspresikan oleh lembaga pendidikan yang sering disebut sebagai pesantren tradisional (salafiyah). Di lain pihak, terdapat sebuah model pesantren yang memang sejak awal didirikan telah mengadopsi sistem klasikal bahkan mengidentifikasikan dirinya sebagai pesantren modern.

Dalam perkembangan mutakhir, tampak semakin sedikit ditemukan sebuah pesantren yang memprioritaskan kepentingan tafaqquh fiddin; mendalami ilmu-ilmu agama dengan spesialisasi keilmuan Islam tertentu, seumpama fiqh atau tafsir. Salah satu di antara alasannya adalah bahwa sebagian besar pesantren juga mengelola lembaga pendidikan formal, baik madrasah, sekolah, bahkan perguruan tinggi umum. Dalam kondisi demikian, maka santri jelas tidak dapat lagi menekuni atau takhassus kitab kuning secara matang, mengingat mereka juga harus menyediakan waktu untuk menekuni mata pelajaran umum.

Perkembangan ini berdampak serius terhadap menurunnya fungsi dan peran pesantren sebagai lembaga pendidikan pencetak ulama. Ulama masa depan sulit - untuk tidak

${ }^{6}$ Berdasarkan observasi langsung peneliti, pola ini misalnya dikembangkan oleh PP. Babakan Ciwaringin Cirebon dan PP. Al-Munawwir Krapyak Yogyakarta. 
mengatakan tidak mungkin - dilahirkan dari sebuah sistem pendidikan umum meskipun ia berada dan dikelola oleh lembaga pesantren sekalipun. Ulama adalah adalah para 'alim yang menekuni dan mendalami ilmu-ilmu agama secara khusus dan matang. Maka, tercerabutnya ilmu agama dari muka bumi ini adalah identik dengan ketiadaan ulama di tengah kehidupan umatnya.

\section{Konsep Mutu}

Mutu biasanya dihubungkan dengan suatu produk atau kualitas layanan. Mutu atau kualitas didefinisikan sebagai sesuatu yang diharapkan para pelanggan (masyarakat) dan dianggap memiliki nilai-nilai tertentu. Jadi untuk menghasilkan sesuatu yang bernilai, didasarkan kepada bagaimana pemahaman pengelolaan lembaga layanan terhadap keinginan dari para pelanggan. ${ }^{7}$ Tegasnya, kualitas adalah sesuai dengan yang diisyaratkan atau sesuai dengan kebutuhan. Artinya, manakala kesesuaian (persyaratan) itu tidak terpenuhi, maka suatu produk atau jasa dikatakan tidak berkualitas. ${ }^{8}$ Persyaratan itu sendiri dapat berubah sesuai dengan keinginan pelanggan, kebutuhan organisasi, pemasok dan sumber, pemerintah, teknologi, serta pasar atau persaingan.

Dalam gambaran yang lebih umum, Goetsch dan Davis menegaskan bahwa kualitas merupakan suatu kondisi dinamis yang berhubungan dengan produk, jasa, manusia, proses dan lingkungan yang memenuhi atau melebihi harapan. ${ }^{9}$ Dalam hal ini, kualitas tidak selalu berhubungan atau mencakup produk dan jasa, melainkan juga meliputi proses, lingkungan dan manusia. Ia adalah apapun

${ }^{7}$ Randall S. Schuler and Drew L. Harris. 1992. Managing Quality: The Primer for Middle Managers. Massachusetts: Adison Weslwy Publishing Company Inc., h. 21.

${ }^{8}$ James W. Cortada. 1993. TQM for Sales and Marketing Management. New York: McGraw-Hill Inc., h. 7 dan 56.

${ }^{9}$ D.L. Goetsch dan Davis. 1994. Introduction to Total Quality: Quality, Productivity, Competitiveness. Englewood Cliffs: Prentice-Hall International Inc, h. 4 yang menjadi kebutuhan dan keinginan konsumen. Jelas, apapun pengertian dasar yang telah disebutkan tadi, tampak sekali bahwa mutu atau kualitas selalu berfokus kepada pelanggan.

Sallis menyebutkan bahwa konsep mutu memiliki tiga pengertian, yaitu mutu sebagai konsep yang absolut mutlak, mutu dalam konsep yang relatif, dan mutu menurut konsumen. ${ }^{10}$ Jika pilihan diberikan kepada mutu dalam konsep yang relatif, maka mutu bukan merupakan atribut dari suatu produk atau jasa. Sesuatu dianggap bermutu jika barang atau jasa telah memenuhi kriteria atau spesifikasi yang telah ditetapkan. Suatu produk atau jasa tidak harus terbaik, tetapi memenuhi standar yang telah ditetapkan.

Dalam konteks pendidikan, pengertian mutu mencakup input, proses dan output. Input pendidikan adalah segala sesuatu yang harus tersedia karena dibutuhkan untuk berlangsungnya proses. Input adalah sesuatu yang sangat berpengaruh terhadap berlangsungnya proses. ${ }^{11}$ Input pendidikan terdiri atas; a) input sumber daya manusia yang mencakup antara lain; kiai, ustadz, karyawan, dan santri, dan sumber daya lainnya, yaitu peralatan, perlengkapan dan sebagainya; b) input perangkat lunak, yaitu struktur organisasi pesantren, peraturan dan tata tertib pesantren, deskripsi tugas, dan lainnya; c) input harapan-harapan berupa visi yang dibangun oleh sebuah pesantren, misi yang dikembangkan, tujuan dan sasaran yang ingin dicapai oleh pesantren.

Sementara proses pendidikan adalah berubahnya sesuatu menjadi sesuatu yang lain. ${ }^{12}$ Dalam konteks pendidikan berskala mikro semisal pesantren, maka proses yang dimaksud adalah proses pengambilan keputusan, proses

\footnotetext{
${ }^{10}$ Edward Sallis. 1993. Total Quality Management in Education. London: Kogan Page, h. 22-24.

${ }_{11}$ Ditjen Dikdasmen, Direktorat SLTP Depdiknas. 2002. Konsep Dasar Manajemen Peningkatan Mutu Berbasis Sekolah. Jakarta: Depdiknas, h. 7

${ }^{12} \mathrm{Ibid}$.
} 
pengelolaan kelembagaan, proses pengelolaan program, proses belajar mengajar, dan proses monitoring dan evaluasi. Proses dikatakan bermutu tinggi apabila pengkoordinasian dan penyerasian serta pemaduan input pesantren (kiai, ustadz, ssantri, kurikulum, biaya, sarana dan prasarana, dsb) dilakukan secara harmonis, sehingganya mampu menciptakan situasi pembelajaran yang menyenangkan, mampu mendorong motivasi dan minat belajar, dan benar-benar mampu memberdayakan santri sebagai peserta didik. Di sini, peserta didik tidak sekadar menguasai pengetahuan yang diajarkan oleh gurunya, tetapi pengetahuan tersebut telah menjadi muatan nurani peserta didik, dihayati, diamalkan. Peserta didik juga mampu belajar secara terus menerus dan mengembangkan dirinya.

Sedangkan output pendidikan merupakan kinerja pesantren. Kinerja pesantren adalah prestasi yang dihasilkan dari proses dan perilaku pendidikan pesantren. Kinerja pesantren dapat diukur dari kualitas, efektivitas, produktivitas, dan inovasi lembaga pesantren, khususnya prestasi belajar santri yang menunjukkan pencapaian yang tinggi dalam prestasi akademik dan prestasi nonakademik. Dengan demikian, pendidikan pesantren dikatakan bermutu tinggi, manakala ia telah mempersiapkan inputnya dengan baik, proses pembelajarannya terlaksana sesuai perencanaan, sehingga menghasilkan output pendidikan yang berkualitas.

\section{Metodologi Penelitian}

Survei dilakukan pada tahun 2014 di seluruh propinsi di Indonesia. Namun pengumpulan datanya hanya dapat dilakukan pada 22 propinsi, yaitu Aceh, Sumut, Sumbar, Riau, Jambi, Sumsel, Lampung, Banten, DKI Jakarta, Jabar, Jateng, DIY, Jatim, Bali, NTB, Kalbar, Kalteng, Kalsel, Kaltim, Sultra, Sulsel, dan Sulteng. 11 propinsi sisanya, tidak dilakukan pengumpulan data dengan alasan, pertama, terjadi perubahan kebijakan terkait anggaran kegiatan, dan kedua, jarak tempuh lokasi penelitian cukup jauh untuk didatangi, sementara jumlah responden rata-rata hanya 1 atau 2 orang.

Jumlah pesantren di 22 propinsi tersebut sebanyak 23.865 , atau $90,8 \%$ dari jumlah total pesantren di seluruh Indonesia, yaitu sebanyak 24.206 (data tahun 2010).

Penelitian ini menggunakan pendekatan kuantitatif dengan metode survai. ${ }^{13}$ Metode ini memberi keleluasaan kepada peneliti untuk memperoleh temuan studi berupa data-data yang bersifat kuantitatif dan kualitatif. Peneliti dapat mentabulasi objek-objek nyata atau mengukur hal-hal yang tidak nyata, seperti pendapat atau pencapaian prestasi tertentu. ${ }^{14}$

Populasi yang menjadi target penelitian adalah seluruh pesantren di di Indonesia. Penelitian ini mengambil sampel penelitian dari salah satu unit populasi, yaitu kiai sebagai pengasuh pesantren. Alasannya, pertama, kiai adalah figur utama pemegang kendali, penggerak dan penentu arah kebijakan pendidikan pesantren. Kedua, seluruh kiai dipilih dengan tanpa perbedaaan kualifikasi, baik secara personal maupun kelembagaan. Tujuannya agar seluruh kiai memiliki peluang yang sama untuk dipilih sebagai sampel. Dengan demikian, karakteristik populasi adalah homogen.

Pengambilan sampel penelitian dilakukan dengan menggunakan teknik acak sistematis (systematic random sampling). ${ }^{15}$ Tahapannya, pertama menentukan jumlah unit populasi dari setiap target populasi, yaitu 24.206 orang kiai. Kedua, menyusun kerangka sampel dalam kelompok dengan cara membagi jumlah populasi dengan jumlah responden. Kelompok

${ }^{13}$ Lihat penjelasan dalam Masri Singarimbun dan Sofyan Effendi. 2006. Metode Penelitian Survai. Jakarta: LP3ES, h. 3-25.

${ }^{14}$ Sevilla et al., 1988. Pengantar Penelitian. Jakarta: UI Press, h. 25

${ }^{15}$ Ibid. h. 162-163. Bandingkan dengan M. Burhan Bungin. 2006. Metodologi Penelitian Kuantitatif. Jakarta: Kencana, h. 115, dan Lina Miftahul Jannah. 2005. Metode Penelitian Kuantitatif: Teori dan Aplikasi. Jakarta: PT. RajaGrafindo Persada, h. 128-130 
$=\mathrm{N} / \mathrm{n}=24.206 / 790=30,6$. Ketiga, memilih satu kelompok yang ada dengan cara acak.

Besaran sampel survai pada tingkat kepercayaan 95\% (MoE 3,5\%) adalah 790. Pemilahan sampel dengan cara acak sistematis (systematic random sampling), menghasilkan sebaran responden di 224 kabupaten/kota di 33 propinsi di Indonesia.

\section{Tabel 1.}

Sebaran Responden pada Kab/Kota/Propinsi Survai Pandangan Kiai terhadap Peningkatan Mutu Kajian Kitab Kuning di Pesantren

\begin{tabular}{|r|l|c|c|c|c|}
\hline \multirow{2}{*}{ No } & \multirow{2}{*}{ Propinsi } & \multicolumn{2}{c|}{ Jumlah } & \multicolumn{2}{c|}{$\begin{array}{c}\text { Sampel } \\
\text { Terjangkau }\end{array}$} \\
\cline { 3 - 6 } & & Kab/Kota & Sampel & Kiai & $\%$ \\
\hline 1 & Aceh & 16 & 35 & 30 & $85,7 \%$ \\
\hline 2 & Sumatera Utara & 7 & 7 & 7 & $100 \%$ \\
\hline 3 & Sumatera Barat & 5 & 7 & 7 & $100 \%$ \\
\hline 4 & Riau & 5 & 6 & 6 & $100 \%$ \\
\hline 5 & Jambi & 6 & 6 & 6 & $100 \%$ \\
\hline 6 & Sumatera Selatan & 5 & 12 & 9 & $75 \%$ \\
\hline 7 & Lampung & 10 & 22 & 16 & $72,7 \%$ \\
\hline 8 & DKI Jaya & 3 & 12 & 6 & $50 \%$ \\
\hline 9 & Jawa Barat & 26 & 243 & 243 & $100 \%$ \\
\hline 10 & Jawa Tengah & 34 & 124 & 108 & $88 \%$ \\
\hline 11 & DI Yogyakarta & 4 & 10 & 10 & $100 \%$ \\
\hline 12 & Jawa Timur & 35 & 144 & 129 & $89,5 \%$ \\
\hline 13 & Banten & 8 & 84 & 82 & $97,6 \%$ \\
\hline 14 & Bali & 3 & 5 & 5 & $100 \%$ \\
\hline 15 & Nusa Tenggara Barat & 7 & 16 & 7 & $43,7 \%$ \\
\hline 16 & Kalimantan Barat & 4 & 6 & 6 & $100 \%$ \\
\hline 17 & Kalimantan Tengah & 4 & 5 & 4 & $80 \%$ \\
\hline 18 & Kalimantan Selatan & 9 & 10 & 10 & $100 \%$ \\
\hline 19 & Kalimantan Timur & 4 & 5 & 5 & $100 \%$ \\
\hline 20 & Sulawesi Tengah & 4 & 5 & 4 & $80 \%$ \\
\hline 21 & Sulawesi Selatan & 7 & 7 & 7 & $100 \%$ \\
\hline 22 & Sulawesi Tenggara & 3 & 5 & 5 & $100 \%$ \\
\hline 23 & Kep. Riau & 1 & 1 & - & - \\
\hline 24 & Babel & 2 & 2 & - & - \\
\hline 25 & Bengkulu & 2 & 2 & - & - \\
\hline 26 & Kep. Riau & 1 & 1 & - & - \\
\hline 27 & Gorontalo & 2 & 2 & - & - \\
\hline 28 & Sulbar & 2 & 2 & - & - \\
\hline 29 & Maluku & 1 & 1 & - & - \\
\hline 30 & Maluku Utara & 1 & 1 & - & - \\
\hline 31 & Nusa Tenggara Timur & 1 & 1 & - & - \\
\hline 32 & Papua & 1 & 1 & - & - \\
\hline 33 & Papua Barat & 1 & 790 & 711 & - \\
\hline & JUMLAH & & & $90,8 \%$ \\
\hline
\end{tabular}

Instrumen yang digunakan berupa kuesioner model pilihan, untuk memperoleh data tentang pandangan kiai terhadap peningkatan mutu kajian kitab kuning di pesantren. Sebelumnya disusun kisi-kisi instrumen. Penyusunan kisi-kisi dan pembahasannya melibatkan seluruh anggota tim peneliti dan ahli di bidang metodologi penelitian. Instrumen yang digunakan dilakukan validasi, yaitu validitas konsep dengan melibatkan ahli di bidang pendidikan pesantren dan metodologi penelitian.

Untuk menilai pandangan kiai terhadap peningkatan mutu kajian kitab kuning di pesantren digunakan metode Likert's Summated Rating (LSR) atau metode rating yang dijumlahkan, yaitu metode penskalaan pernyataan respons yang menggunakan distribusi respons sebagai dasar penentuan nilai skalanya. Pandangan kiai terhadap peningkatan mutu kajian kitab kuning diukur dengan menggunakan tiga (3) indikator, yaitu: pertama, pandangan kiai terhadap aspek input, kedua, pandangan kiai terhadap aspek proses, dan ketiga, pandangan kiai terhadap aspek output.

Masing-masing kiai diminta untuk menyatakan kesetujuannya atau ketidaksetujuannya dalam lima (5) jenjang respons, yaitu: (a) sangat setuju; (b) setuju; (c) ragu-ragu; (d) tidak setuju; dan (e) sangat tidak setuju. Untuk mengukur respons kiai, analisis statistik yang digunakan adalah statistik deskriptif dan statistik inferensi. Teknik analisis statistik deskriptif yang digunakan meliputi distribusi frekuensi, persentase dan tabulasi silang (crosstab). Analisis ini berguna untuk mengetahui tingkat persetujuan Kiai terhadap setiap butir item pertanyaan terkait input, proses dan output pendidikan. Analisis tabulasi silang berguna untuk melihat kecenderungan persetujuan setiap item pertanyaan variabel input, proses dan output berdasarkan kategori demografik responden, seperti latar belakang pendidikan, jenis lembaga pendidikan yang 
dikelola, wilayah provinsi serta pedoman kurikulum.

Sedangkan teknik analisis statistik inferensi yang digunakan adalah analisis korelasi Spearman rho. Analisis ini berguna untuk mengetahui keterkaitan hubungan antara setiap item-item pertanyaan input, proses atau output. Derajat hubungan keterkaitan antara setiap butir pertanyaan diukur dengan koefisien korelasi yang terletak antara $-1 \leq r \leq 1$. Interpretasi koefisien korelasi didasarkan atas 3 (tiga) hal yaitu derajat koefisien korelasi, arah koefisien korelasi serta signifikansi koefisien korelasi. Coolican (1994) mengelompokan interpretasi koefisien korelasi menjadi 5 bagian yaitu $r=0$ (tidak ada korelasi), $r$ terletak antara 0,00 - 0,25 (korelasi sangat lemah), 0,25 - 0,50 (korelasi cukup kuat), 0,50 - 0,75 (korelasi kuat), 0,750,99 (korelasi sangat kuat) dan $\mathrm{r}=1$ (korelasi sempurna). Pengujian signifikansi koefisien korelasi digunakan statistik $\mathrm{t}$ dimana untuk memperoleh signifikansi pengujian statistik $t$ telah secara otomatis dengan software SPSS 15. Nilai signifikansi pengujian kurang dari $\alpha=$ $5 \%$ mengandung arti bahwa koefisien korelasi tersebut bermakna.

\section{HASIL DAN PEMBAHASAN}

\section{Deskripsi Responden}

Dalam penelitian ini, jumlah sampel penelitian terjangkau adalah sebanyak 711 responden. Masing-masing mengisi satu buah instrumen penelitian. Dari 711 instrumen atau kuesioner yang diisi oleh responden, tercatat sebanyak 693 instrumen yang dapat dilakukan pengolahan dan analisis data. Tersisa 18 buah data instrumen yang tidak dapat diolah karena datanya rusak dan atau tidak lengkap. Adapun sebaran responden survai pada setiap propinsi sebagaimana tergambar dalam tabel berikut.
Tabel 2.

Sebaran Lokasi Penelitian (Provinsi) dan Jumlah Responden (\%)

\begin{tabular}{|l|l|c|c|}
\hline No & Provinsi & F & $\%$ \\
\hline 1 & Aceh & 29 & $4.2 \%$ \\
\hline 2 & Sumatera Utara & 7 & $1.0 \%$ \\
\hline 3 & Sumatera Barat & 7 & $1.0 \%$ \\
\hline 4 & Riau & 6 & $0.9 \%$ \\
\hline 5 & Jambi & 5 & $0.7 \%$ \\
\hline 6 & Sumatera Selatan & 8 & $1.2 \%$ \\
\hline 7 & Lampung & 16 & $2.3 \%$ \\
\hline 8 & DKI Jakarta & 11 & $1.6 \%$ \\
\hline 9 & Jawa Barat & 236 & $34.1 \%$ \\
\hline 10 & Jawa Tengah & 108 & $15.6 \%$ \\
\hline 11 & DI Yogya & 9 & $1.3 \%$ \\
\hline 12 & Jawa Timur & 127 & $18.3 \%$ \\
\hline 13 & Banten & 71 & $10.2 \%$ \\
\hline 14 & Bali & 4 & $0.6 \%$ \\
\hline 15 & Nusa Tenggara Barat & 7 & $1.0 \%$ \\
\hline 16 & Kalimantan Barat & 6 & $0.9 \%$ \\
\hline 17 & Kalimantan Tengah & 4 & $0.6 \%$ \\
\hline 18 & Kalimantan Selatan & 10 & $1.4 \%$ \\
\hline 19 & Kalimantan Timur & 5 & $0.7 \%$ \\
\hline 20 & Sulawesi Tenggara & 4 & $0.6 \%$ \\
\hline 21 & Sulawesi Selatan & 8 & $1.2 \%$ \\
\hline 22 & Sulawesi Tengah & 5 & $0.7 \%$ \\
\hline Total & 693 & $100 \%$ \\
\hline Sumber: Survey Pusitbang Pendidian & $98 m a n$ \\
\hline
\end{tabular}

Sumber: Survey Puslitbang Pendidikan Agama dan Keagamaan Tahun 2014

693 data responden dari 22 provinsi di Indonesia, dapat diposisikan mewakili secara merata wilayah Indonesia bagian Barat, Tengah dan Timur. Jumlah sampel penelitian terbesar berada di wilayah Jawa, yaitu Jawa Barat mencapai $(34,1 \%)$, Jawa tengah (15,6\%), Jawa Timur (18,3\%) dan Banten (10,2\%). Sedangkan untuk wilayah Sumatera, tampak Aceh $(4,2 \%)$ sangat dominan. Selanjutnya, untuk provinsi lainnya, jumlah sampel terjangkau kurang dari $2 \%$. 


\section{Aspek Input}

\section{Kelembagaan}

Tabel 3.

Reproduksi Ulama (\%)

\begin{tabular}{|l|l|l|l|l|l|l|l|}
\hline No & Pernyataan & SS & S & RR & TS & STS & Total \\
\hline Q1 & $\begin{array}{l}\text { Pesantren adalah } \\
\text { lembaga pendidikan } \\
\text { pencetak dan } \\
\text { pengkaderan ulama } \\
\text { mutafaqqih fid-din }\end{array}$ & 79.5 & 19.9 & 0.1 & 0.4 & 0.0 & 100 \\
\hline Q2 & $\begin{array}{l}\text { Tugas utama } \\
\text { pendidikan } \\
\text { pesantren adalah } \\
\text { menyiapkan calon } \\
\text { ulama mutafaqqih } \\
\text { fid-din }\end{array}$ & 66.0 & 32.1 & 1.0 & 0.7 & 0.1 & 100 \\
\hline
\end{tabular}

Sumber: Survei Puslitbang Pendidikan Agama dan Keagamaan Tahun 2014

Kiai memberikan tingkat persetujuan yang sangat tinggi bahwa pesantren adalah lembaga untuk mencetak, mengkader dan menyiapkan calon ulama, bahkan hal tersebut merupakan tugas utama pendidikan pesantren (>98\%). Ini artinya peran kesejarahan pesantren sebagai lembaga pencetak ulama harus terus dijaga keberlangsungannya.

Tabel 4.

Struktur Pendidikan (\%)

\begin{tabular}{|l|l|l|l|l|l|l|l|}
\hline No & Pernyataan & SS & S & RR & TS & STS & Total \\
\hline Q3 & $\begin{array}{l}\text { Sistem pendidikan } \\
\text { pesantren disetarakan } \\
\text { (mu'adalah) dengan } \\
\text { lembaga pendidikan } \\
\text { formal }\end{array}$ & 35.3 & 45.3 & 9.3 & 9.7 & 0.4 & 100 \\
\hline Q4 & $\begin{array}{l}\text { Sistem pendidikan } \\
\text { pesantren berjenjang, } \\
\text { yaitu jenjang dasar, } \\
\text { menengah, atas, dan } \\
\text { tinggi }\end{array}$ & 44.3 & 50.4 & 3.2 & 2.0 & 0.0 & 100 \\
\hline Q5 & $\begin{array}{l}\text { Pesantren } \\
\text { mengembangkan } \\
\text { bidang kekhususan, } \\
\text { seperti PP. Tafsir, PP. } \\
\text { Hadis, dll. }\end{array}$ & 27.5 & 55.2 & 7.7 & 9.0 & 0.6 & 100 \\
\hline
\end{tabular}

Sumber: Survei Puslitbang Pendidikan Agama dan Keagamaan Tahun 2014

Demikian halnya, kiai juga memberikan tingkat persetujuan yang sangat tinggi bahwa sistem pendidikan pesantren perlu dibuat berjenjang sesuai dengan tingkat kemampuan santri mempelajari kitab kuning (94,7\%). Namun, bahwa sistem pendidikan pesantren perlu disetarakan dengan pendidikan formal hanya didukung oleh 80,5\% kiai. Sisanya, menyatakan ragu $(9,3 \%)$, bahkan tidak setuju $(9,7 \%)$.

Tabel 5.

Lembaga yang Dikelola versus Kesetaraan Sistem Pendidikan Pesantren (\%)

\begin{tabular}{|l|c|c|c|c|c|c|}
\hline & \multicolumn{5}{|c|}{$\begin{array}{l}\text { Sistem pendidikan pesantren } \\
\text { perlu disetarakan (mu'adalah) } \\
\text { dengan lembaga pendidikan } \\
\text { formal }\end{array}$} \\
\hline Lembaga Pendidikan & SS & S & RR & TS & STS & Total \\
\hline Pesantren & 28 & 48 & 11 & 13 & 0 & 100 \\
\hline Pendidikan Formal & 45 & 39 & 8 & 7 & 1 & 100 \\
\hline $\begin{array}{l}\text { Pesantren dan Pendidikan } \\
\text { Formal }\end{array}$ & 33 & 49 & 8 & 8 & 1 & 100 \\
\hline Total & 35 & 46 & 9 & 10 & 0 & 100 \\
\hline
\end{tabular}

Sumber: Survei Puslitbang Pendidikan Agama dan Keagamaan Tahun 2014

Hasil analisis tabulasi silang di atas menjelaskan bahwa $76 \%$ kiai pengelola pendidikan pesantren saja, cenderung setuju bahwa pendidikan pesantren perlu disetarakan dengan pendidikan formal, dan $13 \%$ di antaranya tidak setuju. Ketidaksetujuan yang lebih rendah diberikan oleh kiai pengelola pesantren plus pendidikan formal $(8,4 \%)$.

\section{Ketenagaan}

Tabel 6.

Kualifikasi dan Kompetensi Akademik Kiai serta Otoritas Kiai (\%)

\begin{tabular}{|l|l|l|l|l|l|l|l|}
\hline No & Pernyataan & SS & S & RR & TS & STS & Total \\
\hline Q6 & $\begin{array}{l}\text { Kiai wajib } \\
\text { berpendidikan } \\
\text { pesantren }\end{array}$ & 72.9 & 24.3 & 1.9 & 0.7 & 0.1 & 100 \\
\hline $\begin{array}{l}\text { Kiai wajib } \\
\text { menguasai salah } \\
\text { satu bidang } \\
\text { keilmuan secara } \\
\text { khusus, seperti ahli } \\
\text { fiqh, ahli tashawuf, } \\
\text { dll }\end{array}$ & 45.7 & 46.4 & 3.5 & 4.0 & 0.4 & 100 \\
\hline Q8 & $\begin{array}{l}\text { Kiai memperluas } \\
\text { ilmunya dengan } \\
\text { mempelajari } \\
\text { kitab kuning dari } \\
\text { berbagai madzhab }\end{array}$ & 48.9 & 47.6 & 2.6 & 0.9 & 0.0 & 100 \\
\hline
\end{tabular}




\begin{tabular}{|l|l|l|l|l|l|l|l|}
\hline No & Pernyataan & SS & S & RR & TS & STS & Total \\
\hline Q9 & $\begin{array}{l}\text { Kebijakan } \\
\text { pengembangan } \\
\text { pendidikan } \\
\text { pesantren tidak } \\
\text { menjadi wewenang } \\
\text { mutlak Kiai semata }\end{array}$ & 24.2 & 57.7 & 7.4 & 9.9 & 0.9 & 100 \\
\hline
\end{tabular}

Sumber: Survei Puslitbang Pendidikan Agama dan Keagamaan Tahun 2014

Faktor kualifikasi dan kompetensi akademik kiai sangat erat kaitannya dengan latar belakang pendidikannya, keluasan ilmunya secara spesifik bahkan pengetahuannya di luar madzhab mayoritas, termasuk otoritas kiai dalam kebijakan pesantren. Bahwa kiai wajib berpendidikan pesantren direspon sangat tinggi $(97,2 \%)$. Demikian halnya bahwa kiai perlu menguasai spesifikasi keilmuan tertentu (92,1\%), serta memperluas ilmunya dengan mempelajari kitab kuning dari berbagai madzhab (96,5\%). Namun demikian, otoritas mutlak kiai atas kebijakan pengembangan pendidikan pesantren masih disetujui oleh $18,1 \%$ Kiai.

Tabel 7.

Pendidikan Kiai versus Kiai Wajib Berpendidikan Pesantren (\%)

\begin{tabular}{|l|l|l|l|l|l|l|}
\hline & \multicolumn{6}{|c|}{ Kiai wajib berpendidikan pesantren } \\
\hline Pendidikan Kiai & SS & S & RR & TS & STS & Total \\
\hline Pesantren & 72 & 25 & 0 & $2 \%$ & 1 & 100 \\
\hline Pendidikan Formal & 73 & 23 & 5 & $0 \%$ & 0 & 100 \\
\hline $\begin{array}{l}\text { Pesantren dan } \\
\text { Pendidikan Formal }\end{array}$ & 73 & 25 & 2 & $1 \%$ & 0 & 100 \\
\hline Total & 73 & 24 & 2 & $1 \%$ & 0 & 100 \\
\hline
\end{tabular}

Sumber: Survei Puslitbang Pendidikan Agama dan Keagamaan Tahun 2014

Hasil analisis tabulasi silang menjelaskan bahwa $96 \%$ kiai berpendidikan non-pesantren cenderung setuju bahwa seorang kiai wajib berpendidikan pesantren. Temuan ini jelas sangat menarik.
Tabel 8.

Lembaga yang Dikelola versus Otoritas Kiai

\begin{tabular}{|l|l|l|l|l|l|l|}
\hline & \multicolumn{6}{|c|}{$\begin{array}{l}\text { Kebijakan pengembangan pend. } \\
\text { pesantren bukan wewenang mutlak } \\
\text { kiai semata }\end{array}$} \\
\hline Lembaga Pendidikan & SS & S & RR & TS & STS & Total \\
\hline Pesantren & 19 & 57 & 11 & 12 & 1 & 100 \\
\hline Pendidikan Formal & 30 & 59 & 3 & 8 & 1 & 100 \\
\hline $\begin{array}{l}\text { Pesantren dan } \\
\text { Pendidikan Formal }\end{array}$ & 25 & 59 & 7 & 9 & 0 & 100 \\
\hline Total & 24 & 58 & 7 & 10 & 1 & 100 \\
\hline
\end{tabular}

Sumber: Survei Puslitbang Pendidikan Agama dan Keagamaan Tahun 2014

Temuan lain yang juga menarik adalah bahwa 76\% kiai pengelola pendidikan pesantren saja, setuju bahwa otoritas pengembangan pesantren bukan hanya milik kiai.

\section{Santri}

Tabel 9.

Mekanisme Penerimaan Santri (\%)

\begin{tabular}{|c|l|c|c|c|c|c|c|}
\hline No & Pernyataan & SS & S & RR & TS & STS & Total \\
\hline Q10 & $\begin{array}{l}\text { Calon santri } \\
\text { baru di tes } \\
\text { kemampuan } \\
\text { dasar bahasa } \\
\text { Arab }\end{array}$ & 12.6 & 48.8 & 14.8 & 22.4 & 1.3 & 100 \\
\hline
\end{tabular}

Sumber: Survei Puslitbang Pendidikan Agama dan Keagamaan Tahun 2014

Bahasa Arab bagi dunia pesantren merupakan hal yang sangat penting, karena seluruh kitab kuning yang dikaji adalah ditulis dengan bahasa Arab. Namun demikian, tidak seluruh kiai setuju adanya tes kemampuan dasar bahasa Arab dalam mekanisme penerimaan santri baru (61,4\%). Tercatat 38,6\% kiai yang memiliki pikiran lain dalam memposisikan bahasa Arab. 
Tabel 10.

\begin{tabular}{|c|c|c|c|c|c|c|c|}
\hline No & Pernyataan & SS & S & $\mathrm{RR}$ & TS & STS & Total \\
\hline Q11 & $\begin{array}{l}\text { Santri memperoleh } \\
\text { pengetahuan } \\
\text { tentang teknik } \\
\text { menulis bahs ilmiah } \\
\text { (karya tulis ilmiah) }\end{array}$ & 21.5 & 63.3 & 9.0 & 6.0 & 0.1 & 100 \\
\hline Q12 & $\begin{array}{l}\text { Santri dibiasakan } \\
\text { menyusun bahs } \\
\text { ilmiah (karya tulis } \\
\text { ilmiah) terutama } \\
\text { dalam bahasa Arab. }\end{array}$ & 21.9 & 62.8 & 11.5 & 3.8 & 0.0 & 100 \\
\hline Q13 & $\begin{array}{l}\text { Santri dilatih } \\
\text { menyajikan bahs } \\
\text { ilmiah (karya tulis } \\
\text { ilmiah) dalam forum } \\
\text { mudzakarah santri }\end{array}$ & 23.6 & 66.4 & 8.1 & 1.9 & 0.0 & 100 \\
\hline
\end{tabular}

Sumber: Survei Puslitbang Pendidikan Agama dan Keagamaan Tahun 2014

Kiai cenderung sepakat agar santri dilatih menyajikan bahs (karya tulis ilmiah) dalam forum mudzakarah santri (90\%), namun respon yang diberikan kiai terhadap keharusan menguasai teknik penulisannya (85\%) dan pembiasaannya dalam pembelajaran (85\%), cenderung lebih rendah. Padahal dua hal yang disebutkan terakhir ini sangat erat kaitannya dengan karya tulis ilmiah.

\section{Sarana dan Prasarana}

Tabel 11

Sarana dan Prasarana yang Dibutuhkan PBM (\%)

\begin{tabular}{|c|c|c|c|c|c|c|c|}
\hline No & Pernyataan & SS & S & RR & TS & STS & Total \\
\hline Q15 & $\begin{array}{l}\text { Perpustakaan } \\
\text { pesantren } \\
\text { dilengkapi kitab- } \\
\text { kitab kuning dari } \\
\text { berbagai madzhab }\end{array}$ & 47.2 & 47.1 & 4.3 & 1.5 & 0.0 & 100 \\
\hline
\end{tabular}

Sumber: Survei Puslitbang Pendidikan Agama dan Keagamaan Tahun 2014

Perpustakaan pesantren adalah sarana yang paling menunjang dalam mempersiapkan santri menjadi seorang ulama. 94,3\% kiai setuju bahwa perpustakaan pesantren perlu dilengkapi kitab-kitab kuning dari berbagai madzhab.

\section{Kurikulum}

Tabel 12.

Struktur Kurikulum (\%)

\begin{tabular}{|c|l|c|c|c|c|c|c|}
\hline No & \multicolumn{1}{|c|}{ Pernyataan } & SS & S & RR & TS & STS & Total \\
\hline Q16 & $\begin{array}{l}\text { Unsur utama } \\
\text { pendidikan pesantren } \\
\text { adalah mempelajari } \\
\text { kitab kuning }\end{array}$ & 47.9 & 43.8 & 4.5 & 3.4 & 0.4 & 100 \\
\hline
\end{tabular}

Sumber: Survei Puslitbang Pendidikan Agama dan Keagamaan Tahun 2014

Pesantren adalah lembaga pengkaderan ulama, dan ulama wajib memahami dan mendalami kitab kuning. Faktanya, 'hanya' 91,7\% kiai setuju bahwa unsur utama pendidikan pesantren adalah mempelajari kitab kuning. 8,3\% kiai bersikap ragu dan tidak setuju.

Tabel 13.

Penguasaan Kurikulum (\%)

\begin{tabular}{|c|c|c|c|c|c|c|c|}
\hline No & Pernyataan & SS & S & RR & TS & STS & Total \\
\hline Q17 & $\begin{array}{l}\text { Tingkat } \\
\text { penguasaan } \\
\text { rata-rata santri } \\
\text { atas kitab kuning } \\
\text { cenderung } \\
\text { menurun }\end{array}$ & 12.4 & 59.5 & 14.5 & 12.1 & 1.5 & 100 \\
\hline Q18 & $\begin{array}{l}\text { Rata-rata } \\
\text { santri hanya } \\
\text { mempelajari kitab } \\
\text { kuning pada } \\
\text { tingkatan dasar }\end{array}$ & 8.4 & 48.6 & 14.8 & 25.6 & 2.6 & 100 \\
\hline Q19 & $\begin{array}{l}\text { Rata-rata bidang } \\
\text { keilmuan yang } \\
\text { dipelajari santri } \\
\text { terbatas, lebih } \\
\text { banyak dalam } \\
\text { ilmu fiqh }\end{array}$ & 6.0 & 47.6 & 14.2 & 30.3 & 1.9 & 100 \\
\hline Q20 & $\begin{array}{l}\text { Motivasi rata- } \\
\text { rata santri untuk } \\
\text { memahami kitab } \\
\text { kuning cenderung } \\
\text { rendah }\end{array}$ & 12.2 & 56.8 & 11.6 & 17.5 & 1.9 & 100 \\
\hline Q21 & $\begin{array}{l}\text { Santri perlu } \\
\text { menguasai } \\
\text { kitab kuning dari } \\
\text { tingkat yang } \\
\text { rendah sampai } \\
\text { tinggi }\end{array}$ & 64.6 & 32.8 & 1.9 & 0.7 & 0.0 & 100 \\
\hline
\end{tabular}

Sumber: Survei Puslitbang Pendidikan Agama dan Keagamaan Tahun 2014

Kiai setuju bahwa santri perlu menguasai kitab kuning dari tingkat dasar hingga tingkat tinggi $(97,4 \%)$, sementara santri saat ini hanya 
mempelajari kitab kuning pada tingkatan dasar (57\%). Para kiai juga menyadari bahwa tingkat penguasaan rata-rata santri atas kitab kuning cenderung menurun (71,9\%), dan bidang keilmuan yang dipelajari pun terbatas ((53,6\%). Motivasi untuk memahami kitab kuning pun rendah (69\%)

Tabel 14.

Korelasi Faktor Penguasaan Kitab Kuning Menurun

\begin{tabular}{|c|l|c|c|c|c|}
\hline No & \multicolumn{1}{|c|}{ Pernyataan } & 1 & 2 & 3 & 4 \\
\hline 1 & $\begin{array}{l}\text { Penguasaan } \\
\text { rata-rata santri } \\
\text { atas kitab kuning } \\
\text { cenderung } \\
\text { menurun }\end{array}$ & 1 & $0.506^{* *}$ & $0.388^{* *}$ & $0.663^{* *}$ \\
\hline 2 & $\begin{array}{l}\text { Santri hanya } \\
\text { mempelajari kitab } \\
\text { kuning pada } \\
\text { tingkatan dasar }\end{array}$ & $\begin{array}{l}\text { Saat ini rata-rata } \\
\text { bidang keilmuan } \\
\text { yang dipelajari } \\
\text { santri terbatas }\end{array}$ & 1 & $0.554^{* *}$ & $0.545^{* *}$ \\
\hline 4 & $\begin{array}{l}\text { Motivasi santri } \\
\text { untuk memahami } \\
\text { kitab kuning } \\
\text { cenderung rendah }\end{array}$ & 1 & $0.500^{* *}$ \\
\hline
\end{tabular}

Keterangan $(* *)$ signifikan pada $\alpha=5 \%$

Sumber: Survei Puslitbang Pendidikan Agama dan Keagamaan Tahun 2014

Hasil analisis korelasi menjelaskan bahwa rendahnya penguasaan santri atas kitab kuning lebih dominan disebabkan oleh rendahnya motivasi santri (korelasi $=0,663$ ), selain disebabkan oleh faktor keterbatasan pembelajaran kitab kuning pada tingkat dasar (korelasi $=0,553$ ) dan faktor bidang keilmuan kitab kuning yang terbatas (korelasi $=0,388$ ).

Tabel 15.

Kesesuaian Kurikulum dengan Kebutuhan (\%)

\begin{tabular}{|c|l|c|c|c|c|c|c|}
\hline No & \multicolumn{1}{|c|}{ Pernyataan } & SS & S & RR & TS & STS & Total \\
\hline Q22 & $\begin{array}{l}\text { Selain kitab kuning, santri } \\
\text { mengkaji kitab-kitab } \\
\text { ashriyah (modern) }\end{array}$ & 31.0 & 57.6 & 7.2 & 3.9 & 0.3 & 100 \\
\hline Q23 & $\begin{array}{l}\text { Santri mengkaji kitab- } \\
\text { kitab dari berbagai } \\
\text { madzhab }\end{array}$ & 30.6 & 56.5 & 9.0 & 4.0 & 0.0 & 100 \\
\hline
\end{tabular}

\begin{tabular}{|c|c|c|c|c|c|c|c|}
\hline No & Pernyataan & SS & S & RR & TS & STS & Total \\
\hline Q24 & $\begin{array}{l}\text { Kitab kuning yang } \\
\text { dipelajari santri } \\
\text { disesuaikan dengan } \\
\text { tingkat kemampuan } \\
\text { santri }\end{array}$ & 44.8 & 51.6 & 1.9 & 1.6 & 0.1 & 100 \\
\hline Q25 & $\begin{array}{l}\text { Pesantren menyusun } \\
\text { daftar tingkatan kitab } \\
\text { kuning yang harus } \\
\text { dikuasai santri, mulai } \\
\text { tingkat yang rendah, } \\
\text { sedang sampai tinggi } \\
\text { sesuai jenjangnya }\end{array}$ & 47.2 & 49.1 & 3.6 & 0.1 & 0.0 & 100 \\
\hline Q26 & $\begin{array}{l}\text { Pesantren menyusun } \\
\text { sebuah pedoman } \\
\text { pengajian kitab kuning } \\
\text { yang disepakati bersama } \\
\text { oleh seluruh pesantren }\end{array}$ & 20.8 & 55.1 & 13.0 & 10.9 & 0.1 & 100 \\
\hline Q27 & $\begin{array}{l}\text { Pedoman pengajian kitab } \\
\text { kuning dibutuhkan untuk } \\
\text { memastikan bahwa santri } \\
\text { telah mempelajari kitab } \\
\text { kuning pada seluruh } \\
\text { bidang keilmuan sesuai } \\
\text { jenjangnya }\end{array}$ & 21.0 & 70.7 & 6.3 & 2.0 & 0.0 & 100 \\
\hline Q28 & $\begin{array}{l}\text { Pedoman pengajian } \\
\text { kitab kuning dibutuhkan } \\
\text { sebagai acuan } \\
\text { dalam perencanaan, } \\
\text { pelaksanaan dan } \\
\text { evaluasi kajian kitab } \\
\text { kuning }\end{array}$ & 22.8 & 71.9 & 3.7 & 1.6 & 0.0 & 100 \\
\hline
\end{tabular}

Sumber: Survei Puslitbang Pendidikan Agama dan Keagamaan Tahun 2014

Terkait kesesuaian kurikulum dengan kebutuhan, kiai memberikan respon ratarata $87,1 \%$ - $88,6 \%$ atas pentingnya santri mengkaji kitab berbagai madzhab dan kitabkitab ashriyah. Namun demikian, persetujuan kiai lebih tinggi bahwa pembelajaran kitab kuning perlu disesuaikan dengan tingkat kemampuan santri $(96,4 \%)$, dan caranya adalah dengan menyusun standar kitab kuning sesuai jenjangnya $(96,2 \%)$.

Para kiai setuju bahwa kajian kitab kuning membutuhkan sebuah pedoman sebagai acuan dalam perencanaan, pelaksanaan dan evaluasi pembelajaran $(94,7 \%)$, selain sebagai tolak ukur untuk memastikan bidang keilmuan yang dipelajari sesuai jenjangnya (97,1\%). Namun demikian, tentang cara menghadirkan pedoman dimaksud, tampaknya pendapat 
para kiai tidak cukup utuh. Jika $76 \%$ kiai setuju bahwa mereka harus duduk bersama, menyusun dan menyepakati pedoman tersebut untuk kemudian menggunakannya secara bersama-sama, maka $24 \%$ kiai cenderung ragu dan atau tidak setuju.

\section{Aspek Proses}

\section{Pelaksanaan Proses Belajar Mengajar}

Tabel 16.

Perencanaan Pembelajaran (\%)

\begin{tabular}{|c|l|c|c|c|c|c|c|}
\hline No & \multicolumn{1}{|c|}{ Pernyataan } & SS & S & RR & TS & STS & Total \\
\hline Q1 & $\begin{array}{l}\text { Pesantren menyusun } \\
\text { indikator pencapaian } \\
\text { kompetensi santri } \\
\text { dalam pengajian kitab } \\
\text { kuning }\end{array}$ & 25.7 & 63.6 & 7.2 & 3.5 & 0.0 & 100 \\
\hline Q2 & $\begin{array}{l}\text { Materi dalam } \\
\text { pengajian kitab kuning } \\
\text { disusun per semester }\end{array}$ & 17.1 & 61.1 & 11.1 & 10.6 & 0.1 & 100 \\
\hline
\end{tabular}

Sumber: Survei Puslitbang Pendidikan Agama dan Keagamaan Tahun 2014

Respon kiai bahwa pesantren perlu menyusun indikator pencapaian kompetensi dalam pengajian kitab kuning cukup tinggi, yaitu 89,3\%. Demikian halnya tentang pentingnya pengaturan pembelajaran per semester $(78,2 \%)$.

Tabel 17.

Waktu Pembelajaran (\%)

\begin{tabular}{|c|l|c|c|c|c|c|c|}
\hline No & \multicolumn{1}{|c|}{ Pernyataan } & SS & S & RR & TS & STS & Total \\
\hline Q3 & $\begin{array}{l}\text { Waktu yang } \\
\text { digunakan santri } \\
\text { lebih banyak di } \\
\text { madrasah atau } \\
\text { sekolah }\end{array}$ & 12.4 & 49.9 & 16.5 & 20.0 & 1.2 & 100 \\
\hline Q4 & $\begin{array}{l}\text { Waktu yang dimiliki } \\
\text { santri dalam } \\
\text { mempelajari kitab } \\
\text { kuning semakin } \\
\text { sedikit dalam setiap } \\
\text { harinya. }\end{array}$ & 9.5 & 42.5 & 11.8 & 32.2 & 4.0 & 100 \\
\hline
\end{tabular}

Sumber: Survei Puslitbang Pendidikan Agama dan Keagamaan Tahun 2014
Persetujuan kiai cukup rendah $(62,3 \%)$ bahwa waktu yang digunakan santri saat ini lebih banyak di madrasah atau sekolah, dan waktu santri untuk mempelajari kitab kuning semakin sedikit (52\%). Meskipun demikian, ternyata ada korelasi yang signifikan antara dimensi waktu yang semakin sedikit dengan rata-rata penurunan minat dalam mempelajari kitab kuning.

Tabel 18.

Korelasi Faktor Penguasaan Santri Menurun dengan Waktu yang Dimiliki

\begin{tabular}{|c|c|c|c|c|}
\hline No & Pernyataan & 1 & 2 & 3 \\
\hline 1 & $\begin{array}{l}\text { Tingkat penguasaan rata-rata } \\
\text { santri atas kitab kuning cenderung } \\
\text { menurun }\end{array}$ & 1 & $0.085^{\star *}$ & $0.356^{* *}$ \\
\hline 2 & $\begin{array}{l}\text { Waktu yang digunakan santri lebih } \\
\text { banyak di madrasah atau sekolah }\end{array}$ & - & 1 & $0.259^{\star *}$ \\
\hline 3 & $\begin{array}{l}\text { Waktu yang dimiliki santri dalam } \\
\text { mempelajari kitab kuning semakin } \\
\text { sedikit dalam setiap harinya. }\end{array}$ & - & - & 1 \\
\hline
\end{tabular}

Sumber: Survey Puslitbang Pendidikan Agama dan Keagamaan Tahun 2014

Hasil analisis korelasi menjelaskan adanya korelasi yang signifikan pada $\alpha=$ $5 \%$ antara rata-rata penguasaan santri atas kitab kuning dengan waktu yang digunakan santri yang lebih banyak di madrasah/ sekolah $(0,085)$. Meski derajat keterkaitan hubungan kedua pernyataan tersebut tingkat korelasinya rendah. Namun demikian, dari sisi minimnya waktu yang digunakan santri dalam mempelajari kitab kuning, tampak memiliki korelasi yang lebih tinggi dengan rata-rata penguasaan santri akan kitab kuning yang semakin menurun $(0,356)$. Hal ini mengindikasikan bahwa keterbatasan faktor waktu mempelajari kitab kuning dapat menjadi pemicu rendahnya penguasaan santri atas kitab kuning. 
Tabel 19. Strategi Pembelajaran (\%)

\begin{tabular}{|c|c|c|c|c|c|c|c|}
\hline No & Pernyataan & SS & $S$ & $\mathrm{RR}$ & TS & STS & Tota \\
\hline Q5 & $\begin{array}{l}\text { Memahami kitab } \\
\text { kuning diperkaya } \\
\text { dengan mengetahui } \\
\text { latar belakang } \\
\text { kehidupan penulis } \\
\text { kitabnya }\end{array}$ & 19.1 & 64.3 & 9.5 & 6.6 & 0.4 & 100 \\
\hline Q6 & $\begin{array}{l}\text { Memahami kitab } \\
\text { kuning diperkaya } \\
\text { dengan mengetahui } \\
\text { latar belakang sosial } \\
\text { dan politik saat kitab } \\
\text { tersebut ditulis }\end{array}$ & 11.8 & 53.3 & 16.2 & 16.6 & 2.1 & 100 \\
\hline Q7 & $\begin{array}{l}\text { Memahami kitab } \\
\text { kuning diperkaya } \\
\text { dengan pendekatan } \\
\text { ilmu-ilmu lain, } \\
\text { seperti sosiologi dan } \\
\text { antropologi }\end{array}$ & 15.7 & 58.5 & 13.9 & 11.1 & 0.7 & 100 \\
\hline Q8 & $\begin{array}{l}\text { Memahami kitab } \\
\text { kuning diperkaya } \\
\text { dengan menguasai } \\
\text { manhajul fikr-nya }\end{array}$ & 16.9 & 73.5 & 7.2 & 2.4 & 0.0 & 100 \\
\hline Q9 & $\begin{array}{l}\text { Memahami kitab } \\
\text { kuning diperkaya } \\
\text { dengan mendalami } \\
\text { thoriqot istinbat al- } \\
\text { hukm-nya }\end{array}$ & 21.9 & 66.2 & 7.7 & 4.0 & 0.1 & 10 \\
\hline
\end{tabular}

Sumber: Survei Puslitbang Pendidikan Agama dan Keagamaan Tahun 2014

Strategi pembelajaran kitab kuning yang paling penting dalam pandangan kiai adalah memahami kitab kuning dengan menguasai manhajul fikr-nya $(90,4 \%)$, kemudian diperkaya dengan mandalami thoriqot istinbat al-hukmnya $(88,1 \%)$, dilanjutkan dengan mengetahui latar belakang kehidupan penulisnya $(83,1 \%)$. Setelahitu, perlu diperkaya dengan pendekatan ilmu-ilmu lain (74,2\%), dan yang terakhir, memahami kitab kuning dengan mengetahui latar belakang sosial dan politik saat kitab itu ditulis $(65,1 \%)$.

Hanya saja, kelima pernyataan di atas sesungguhnya tidak untuk dilakukan stratifikasi. Misalnya, mengetahui "latar belakang sosial politik" yang dinilai terendah oleh para kiai, sesungguhnya sama pentingnya dengan menguasai manhajul fikr yang dinilai tertinggi. Sebab, mengetahui latar belakang sosial politik saat sebuah kitab ditulis, akan memposisikan kita lebih obyektif memahami jalan pikiran yang ditawarkan oleh kitab tersebut. Pasalnya, sebagaimana diketahui bahwa tak jarang sebuah buku ditulis untuk sebuah kepentingan tertentu. Misalnya, ditulis untuk kebutuhan penguasa atau sebuah kekuasaan. Maka dapat dimaklumi jika kecenderungan buku tersebuat menjadi bias penguasa.

Tabel 20.

Penggunaan Sumber Belajar (\%)

\begin{tabular}{|c|l|c|c|c|c|c|c|}
\hline No & \multicolumn{1}{|c|}{ Pernyataan } & SS & S & RR & TS & STS & Total \\
\hline Q10 & $\begin{array}{l}\text { Saat ini jenis kitab } \\
\text { kuning yang dipelajari } \\
\text { santri pada setiap } \\
\text { bidang keilmuan } \\
\text { adalah terbatas }\end{array}$ & 7.7 & 54.2 & 13.2 & 23.7 & 1.2 & 100 \\
\hline Q11 & $\begin{array}{l}\text { Santri perlu dibiasakan } \\
\text { menyelenggarakan } \\
\text { mudzakarah atau } \\
\text { bahtsul masail dengan } \\
\text { dukungan sarana } \\
\text { perpustakaan yang } \\
\text { memadai }\end{array}$ & 49.0 & 49.6 & 1.0 & 0.4 & 0.0 & 100 \\
\hline
\end{tabular}

Sumber: Survei Puslitbang Pendidikan Agama dan Keagamaan Tahun 2014

Terkait penggunaan sumber belajar bahwa jenis kitab kuning yang dipelajari oleh santri dinilai terbatas direspon beragam oleh para kiai dengan tingkat persetujuan $61,9 \%$. Hal ini dapat berindikasi terhadap rata-rata penurunan penguasaan santri atas kitab kuning.

\section{Evaluasi Proses Belajar Mengajar}

Tabel 21.

Pelaksanaan dan Model Evaluasi (\%)

\begin{tabular}{|c|l|c|c|c|c|c|c|}
\hline No & Pernyataan & SS & S & RR & TS & STS & Total \\
\hline Q12 & $\begin{array}{l}\text { Secara berkala, tingkat } \\
\text { kemampuan santri } \\
\text { mengkaji kitab kuning } \\
\text { diuji dalam sebuah } \\
\text { imtihan sanawi. }\end{array}$ & 38.1 & 58.3 & 2.8 & 0.9 & 0.0 & 100 \\
\hline
\end{tabular}

Sumber: Survei Puslitbang Pendidikan Agama dan Keagamaan Tahun 2014 
Respon para kiai terhadap evaluasi hasil belajar sangat tinggi (96,3\%). Maknanya, para kiai meyakini bahwa evaluasi hasil belajar sangat penting untuk menguji kompetensi santri dan menilai hasil belajar.

\section{Aspek Output}

\section{Prestasi Akademik}

Tabel 22.

Raport dan ljazah (\%)

\begin{tabular}{|c|l|c|c|c|c|c|c|}
\hline No & \multicolumn{1}{|c|}{ Pernyataan } & SS & S & RR & TS & STS & Total \\
\hline Q1 & $\begin{array}{l}\text { Hasil imtihan sanawi } \\
\text { santri dicatat dalam } \\
\text { Buku Raport }\end{array}$ & 36.1 & 55.4 & 4.5 & 3.7 & 0.3 & 100 \\
\hline Q2 & $\begin{array}{l}\text { Santri yang telah } \\
\text { menyelesaikan } \\
\text { pendidikan pada akhir } \\
\text { jenjang diberikan tanda } \\
\text { kelulusan atau ijazah }\end{array}$ & 42.8 & 50.7 & 4.0 & 2.5 & 0.0 & 100 \\
\hline Q3 & $\begin{array}{l}\text { Tanda kelulusan } \\
\text { santri atau ijazah } \\
\text { dari pesantren diakui } \\
\text { legalitasnya oleh } \\
\text { Pemerintah }\end{array}$ & 53.1 & 38.8 & 4.3 & 3.5 & 0.3 & 100 \\
\hline
\end{tabular}

Sumber: Survei Puslitbang Pendidikan Agama dan Keagamaan Tahun 2014

Keberadaan buku raport dan tanda kelulusan atau ijazah yang diakui legalitasnya oleh pemerintah didukung oleh lebih dari 91\% Kiai. Hal ini menunjukkan bahwa pada dasarnya pesantren meyakini pentingnya instrumen pendidikan formal yang menunjukkan data akademik santri. Persetujuan para kiai atas ijazah lulusan pesantren yang diakui legalitasnya oleh Pemerintah menjaditestimoni bahwa pihak pesantren dapat merespon instrumen pendidikan formal tersebut yang senyatanya sangat dibutuhkan manakala santri ingin melanjutkan pendidikannya ke jenjang yang lebih tinggi.

\section{PENUTUP}

\section{Kesimpulan}

Berdasarkan respon kiai terhadap sejumlah indikator yang digunakan untuk mengukur variabel input, proses dan output, dapat disimpulkan bahwa pada aspek kelembagaan, rata-rata kiai memberikan respon tinggi terhadap fungsi pesantren sebagai lembaga reproduksi ulama, sistem jenjang pendidikan, serta perlunya kesetaraan dengan lembaga formal. Kiai juga setuju untuk mendistribusikan otoritas tata kelola lembaga pesantren dengan banyak pihak. Para kiai juga merespon sangat positif terhadap kewajiban kiai berpendidikan pesantren serta kompetensinya di berbagai bidang keilmuan, bahkan keilmuan di luar madzhab. Oleh karena itu, kiai merespon sangat baik pentingnya perpustakaan pesantren menghimpun kitabkitab kuning dari berbagai madzhab.

Pada aspek peserta didik, para kiai merespon baik pentingnya santri diberikan pengetahuan tentang karya tulis ilmiah, teknik penulisannya serta menyajikannya dalam forum mudzakarah, selain dilatih melakukan tahqiq al-kutub. Sementara itu, kiai tidak sepenuhnya setuju adanya tes kemampuan dasar bahasa Arab dalam mekanisme penerimaan santri baru. Tetapi, santri perlu menguasai kitab kuning pada seluruh tingkatan, meski saat ini rata-rata santri hanya mempelajari kitab kuning pada tingkatan dasar. Para kiai menyadari bahwa tingkat penguasaan rata-rata santri atas kitab kuning cenderung menurun, dan bidang keilmuan yang dipelajari pun terbatas. Persetujuan kiai pun cukup rendah bahwa waktu yang digunakan santri saat ini lebih banyak di madrasah atau sekolah, dan waktu santri untuk mempelajari kitab kuning semakin sedikit. Meskipun demikian, ternyata ada korelasi yang signifikan antara dimensi waktu yang semakin sedikit dengan rata-rata penurunan minat dalam mempelajari kitab kuning. 
Pada aspek kurikulum, para kiai setuju bahwa unsur utama kurikulum pendidikan pesantren adalah mempelajari kitab kuning. Kajian kitab kuning membutuhkan sebuah pedoman sebagai acuan dalam perencanaan, pelaksanaan dan evaluasi pembelajaran, selain sebagai tolak ukur untuk memastikan bidang keilmuan yang dipelajari sesuai jenjangnya. Namun demikian, tentang cara menghadirkan pedoman dimaksud, pendapat para kiai tidak utuh. Sebagian kecil kiai tidak setuju manakala harus menyusun dan menyepakati pedoman tersebut untuk kemudian menggunakannya secara bersama-sama. Tampaknya, otoritas kiai tidak sepenuhnya bisa diintervensi pihak lain.

Strategi pembelajaran yang penting dalam pandangan kiai adalah memahami kitab kuning dengan menguasai manhajul fikr-nya, kemudian diperkaya dengan cara mandalami thoriqot istinbat al-hukm-nya, dilanjutkan dengan mengetahui latar belakang kehidupan penulisnya. Setelah itu, perlu diperkaya dengan pendekatan ilmu-ilmu lain, dan yang terakhir, memahami kitab kuning dengan mengetahui latar belakang sosial dan politik saat kitab itu ditulis.

Terakhir, terkait dengan prestasi akademik santri, tampak sekali bahwa keberadaan buku raport dan tanda kelulusan atau ijazah yang diakui legalitasnya oleh pemerintah direspon dengan sangat baik oleh para kiai. Kiai meyakini pentingnya instrumen pendidikan yang menunjukkan data akademik santri yang senyatanya sangat dibutuhkan manakala santri ingin melanjutkan pendidikannya ke jenjang yang lebih tinggi.

Berbagai temuan penelitian di atas, menjadi testimoni faktual bahwa rata-rata kiai memiliki pandangan positif terhadap peningkatan mutu kajian kitab kuning di pesantren pada seluruh aspek, baik aspek input, proses maupun output.

\section{Rekomendasi}

Pertama, Direktorat Pendidikan Diniyah dan Pondok Pesantren Ditjen Pendidikan Islam Kementerian Agama RI bersama-sama pondok pesantren perlu merumuskan grand design kaderisasi ulama mutafaqqih fid-din dengan konsentrasi kajian kitab kuning. Tegasnya, perlu sebuah satuan atau program atau jenis pendidikan kader ulama di pesantren yang akan menggunakan kitab kuning sebagai sumber belajar pada seluruh struktur kurikulumnya. Ia adalah pendidikan yang terarah, terencana dan berkelanjutan yang dimulai sejak pendidikan dasar, menengah, atas hingga jenjang pendidikan tinggi.

Memberikan bantuan sumberdaya pendidikan, melindungi kemandirian dan kekhasannya, serta melakukan akreditasi untuk penjaminan dan pengendalian mutu pendidikan sesuai Standar Nasional Pendidikan.

Kedua, kepada Puslitbang Pendidikan Agama dan Keagamaan, untuk menjadi bagian dari supporting system dalam konteks peningkatan mutu terhadap satuan atau program atau jenis pendidikan kader ulama mutafaqqih fid-din di pesantren.

Ketiga, kepada pondok pesantren, untuk memformulasikan beragam bentuk dan model kajian kitab kuning di pesantren masingmasing kepada satuan atau program atau jenis pendidikan kader ulama mutafaqqih fid-din yang akan dikembangkan oleh Pemerintah berdasarkan kesepakatan dengan seluruh kiai pengelola pesantren. 


\section{SUMBER BACAAN}

\section{Peraturan-peraturan}

Undang-undang Nomor 20 Tahun 2003 tentang Sistem Pendidikan Nasional

Peraturan Pemerintah Nomor 19 Tahun 2005 tentang Standar Nasional Pendidikan.

Peraturan Pemerintah Nomor 55 Tahun 2007 tentang Pendidikan Agama dan Pendidikan Keagamaan

Peraturan Menteri Agama Nomor 13 Tahun 2014 tentang Pendidikan Keagamaan Islam

\section{Buku-buku}

An-Nahidl, Nunu Ahmad dkk (Editor) (2010): Otoritas Pesantren dan Perubahan Sosial. Jakarta, Puslitbang Pendidikan Agama dan Keagamaan.

Badan Litbang dan Diklat (2011): Survei Pengajaran Kitab Kuning di Pondok Pesantren. Jakarta, Puslitbang Pendidikan Agama dan Keagamaan.

Badan Litbang dan Diklat (2013): Laporan Halaqah Ulama tentang "Penguatan Tradisi Keilmuan di Pondok Pesantren. Jakarta, Puslitbang Pendidikan Agama dan Keagamaan.

Bungin, M. Burhan (2006). Metodologi Penelitian Kuantitatif. Jakarta, Kencana.

Cortada, James W. (1993). TQM for Sales and Marketing Management. New York, McGrawHill Inc.

Dhofier, Zamakhsyari (1982): Tradisi Pesantren: Studi tentang Pandangan Hidup Kyai. Jakarta, LP3ES.
Ditjen Dikdasmen, Direktorat SLTP Depdiknas (2002): Konsep Dasar Manajemen Peningkatan Mutu Berbasis Sekolah. Jakarta, Depdiknas.

D.L. Goetsch and Davis (1994): Introduction to Total Quality: Quality, Productivity, Competitiveness. Englewood Cliffs, PrenticeHall International Inc.

Mastuhu (1994): Dinamika sistem Pendidikan Pesantren. Jakarta, INIS.

Mas'udi, Masdar F (1985): "Mengenal Pemikiran Kitab Kuning," dalam M. Dawam Rahardjo (editor): Pergulatan Dunia Pesantren: Membangun dari Bawah. Jakarta, P3M.

Miftahul Jannah, Lina (2005): Metode Penelitian Kuantitatif: Teori dan Aplikasi. Jakarta, PT. RajaGrafindo Persada.

Mochtar, Affandi (1999): "Tradisi Kitab Kuninng: Sebuah Observasi Umum," dalam Marzuki Wahid, dkk (penyunting), Pesantren Masa Depan: Wacana Pemberdayaan dan Transformasi Pesantren. Bandung, Pustaka Hidayah.

Sallis, Edward (1993): Total Quality Management in Education. London, Kogan Page.

Schuler, Randall S. and Drew L. Harris (1992): Managing Quality: The Primer for Middle Managers. Massachusetts, Adison Weslwy Publishing Company Inc.

Sevilla et al. (1988): Pengantar Penelitian. Jakarta, UI Press.

Singarimbun, Masri dan Sofyan Effendi (2006): Metode Penelitian Survai. Jakarta, LP3ES. 